\title{
Lack of Native Vegetation Recovery Following Biological Control of Leafy Spurge
}

\author{
Jack L. Butler ${ }^{1}$ and Stefanie D. Wacker ${ }^{2}$ \\ Authors are ${ }^{1}$ Supervisory Ecologist and and ${ }^{2}$ Ecologist, US Department of Agriculture Forest Service, Rocky Mountain Research Station, Forest and \\ Grassland Research Laboratory, Rapid City, SD 57702, USA.
}

\begin{abstract}
Leafy spurge (Euphorbia esula L.) is an aggressive exotic species that has been successfully suppressed in a variety of situations using classical biological control (flea beetles; Aphthona spp.). This 9-yr study investigated patterns of vegetation responses following significant reductions in leafy spurge cover and density by flea beetles in southeastern Montana. We hypothesized that the vegetation following leafy spurge suppression would be dominated by species and plant functional groups able to persist through heavy infestations. Flea beetles were first released in 1998, and by 2006 leafy spurge foliar cover was reduced $80 \%$ to $90 \%$ compared to 1998 values on both release and nonrelease plots. Although total cover of the resident vegetation, excluding leafy spurge, increased $72 \%$ to $88 \%$, relative cover of the functional groups (native forbs, native sedges, native grasses, and nonnative species) was similar among years and between release and nonrelease plots. Mean diversity and mean species richness values did not differ among years or between release and nonrelease plots $(P<0.05)$, but mean diversity on both release and nonrelease plots was significantly less than noninfested plots, although richness was similar $(P<0.05)$. Indicator species analysis revealed that non-native Poa spp. replaced leafy spurge as the dominant species on release and nonrelease plots. Conversely, noninfested plots contained a variety of native species with high indicator values. Although total abundance of the resident vegetation in 2006 was significantly greater than 1998, plant species composition and relative cover showed little change for the duration of the study. Failure of the native vegetation to recover to a community that approached nearby noninfested conditions may be attributed to a variety of interacting scenarios, some of which may be ameliorated by treating infestations as soon as possible to avoid long-term residual effects.
\end{abstract}

\section{Resumen}

El euforbio de montaña (Euphorbia esula L.) es una especie exótica agresiva que ha sido exitosamente suprimida en un gran variedad de situaciones usando el clásico control biológico (flea beetles; Aphthona spp.). Durante estos 9 años de estudio, investigamos los patrones de la respuesta de la vegetación después de una reducción significativa en la cobertura y densidad del euforbio de montaña mediante el uso de escarabajos en el sureste de Montana. Nuestra hipótesis era que especies y grupos de plantas funcionales capaces de persistir a través de graves infestaciones dominarían la vegetación después de la supresión de euforbio de montaña. Los escarabajos se liberaron por primera vez en 1998 y para el 2006 la cobertura foliar del euforbio de montaña se había reducido en un $80 \%$ a 90\% comparada con los valores de 1998 en parcelas donde se liberaron y donde no se liberaron los escarabajos. Aunque la cobertura total del la vegetación residente excluyendo euforbio de montaña, incrementó de $72 \%$ a $88 \%$, la cobertura relativa de los grupos funcionales (herbáceas nativas, juncias nativas, pastos nativos y especies no nativas) fue similar entre ambos y entre parcelas donde fueron liberadas y donde no fueron liberadas. La media de la diversidad y los valores de la media de la riqueza no fueron diferentes entre años entre parcelas liberadas o no liberadas $(P<0.05)$, pero la media de la diversidad en ambos parcelas liberadas y no liberadas fue significativamente menor que en parcelas no infestadas, aunque la riqueza fue similar $(P<0.05)$. Análisis de las especies claves revelaron que especies no nativas Poa spp. reemplazaron euforbio de montaña como la especie dominante en parcelas donde hubo y no hubo liberaciones. Por el contrario parcelas no infectadas contuvieron una variedad de especies nativas con altos valores indicadores. Aunque la abundancia total de la vegetación nativa en 2006 fue significativamente mayor que en el 1998, la composición de las especies de plantas y la cobertura relativa mostraron un ligero cambio durante la duración del estudio. El fracaso de la vegetación nativa para recubrir la comunidad que se acercaba a las inmediaciones de las parcelas no infestadas puede atribuirse a la variedad de interacciones de las circunstancias, algunos de las cuales pueden mejorarse tratando las infestaciones lo antes posible para evitar efectos residuales a largo plazo.

Key Words: biological weed control, Euphorbia esula, exotic invasive, flea beetle, Northern Great Plains, restoration ecology

This research was funded in part by the US Department of Agriculture Agricultural Research Service, TEAM Leafy Spurge Project administered by the Northern Plains Agricultural Research Laboratory, Sidney, MT, and the US Forest Service, Rocky Mountain Research Station.

Mention of a proprietary product does not constitute a guarantee or warranty of the product by USDA or the authors and does not imply its approval to the exclusion of the other products that also may be suitable.

Correspondence: Jack L. Butler, US Department of Agriculture Forest Service, Rocky Mountain Research Station, Forest and Grassland Research Laboratory, 8221 S Highway 16, Rapid City, SD 57702, USA. Email: jackbutler@fs.fed.us

Manuscript received 8 June 2009; manuscript accepted 24 May 2010.

\section{INTRODUCTION}

Leafy spurge (Euphorbia esula L.) is an invasive plant of Eurasian origin that was first discovered in North America in the 1800s (Selleck et al. 1962). It is a deeply rooted perennial capable of rapid and aggressive vegetative expansion. Leafy spurge is widely distributed throughout much of the western United States and Canadian provinces where it is well recognized for having wide ecological tolerances (Selleck et al. 1962) and broad competitive effects on local species 
distribution and abundance (Lym and Messersmith 1985; Lym and Kirby 1987; Belcher and Wilson 1989; Butler and Cogan 2004). Efforts to control leafy spurge generally involve herbicides, mechanical control, and biological control used either singly or in combination (Lym 1998; Joshi 2008). Black beetles (Aphthona lacertosa and A. czwalinae) and brown beetles (A. nigriscutis) represent some of the more successful biological control agents used to control and manage leafy spurge on a relatively large scale in a variety of situations (Hansen et al. 1997; Lym 1998; Kirby et al. 2000; Lym and Nelson 2000, 2002; Larson and Grace 2004; Lesica and Hanna 2004; Butler et al. 2006; Cornett et al. 2006; Larson et al. 2008; Samuel et al. 2008). In June 1998, biological control assessment teams associated with The Ecological Areawide Management of Leafy Spurge (TEAM Leafy Spurge) released black and brown flea beetles in select areas of Montana, North Dakota, South Dakota, and Wyoming (US Department of Agriculture [USDA], Agricultural Research Service 2005). Butler et al. (2006) evaluated the dynamics and trends of flea beetle populations, leafy spurge stands, and resident vegetation within the Montana and South Dakota study areas. In that study, black flea beetle abundance increased rapidly within 2 yr following the 1998 releases. Leafy spurge stem density and foliar cover decreased $66 \%$ to $79 \%$ in both study areas while graminoid cover increased almost $60 \%$ during the same 2 -yr time period. However, at the end of the 6-yr evaluation period (2004), foliar cover of forbs and graminoids was not statistically different from values recorded prior to release of the insects.

Although considerable effort has been dedicated to evaluating various control and management strategies for leafy spurge and the general reaction of the resident vegetation (Lym and Messersmith 1985; Kirby et al. 2000; Butler et al. 2006), relatively long-term studies that provide more detailed information on the responses of the resident vegetation released from the competitive effects of an aggressive invasive species such as leafy spurge are limited (Denslow and D'Antonio 2005; Bush et al. 2007). Previous research has indicated that infestations of leafy spurge differentially impact species composition and functional group diversity of invaded plant communities (Belcher and Wilson 1989; Butler and Cogan 2004). For example, forbs as a group appear to be especially sensitive to heavy infestations of leafy spurge while certain species of graminoids tend to persist (Butler and Cogan 2004). Such a filtering effect could have profound implications for vegetation recovery following successful suppression of the target species. The objective of this study was to evaluate specific responses of the native vegetation following the relatively rapid reduction of leafy spurge using classical biological control. Specifically, we hypothesized that following biological control of leafy spurge 1) the plant community would be characterized by species and functional types that were able to persist on infested sites, 2) native plant species richness and diversity would remain similar to that of sites invaded by leafy spurge and dissimilar to noninfested (preinvasion) sites for the duration of the study, and 3) the removal of leafy spurge would provide opportunities for establishment of new non-native species and/or increased dominance of existing non-native species. Further, we predicted that observed patterns in vegetation response would be significantly influenced by soil fertility. Insight into the specific patterns of vegetation recovery following reductions in leafy spurge dominance is essential for defining successful biological control and for developing and evaluating management alternatives.

\section{MATERIALS AND METHODS}

\section{Site Description}

The study site (2600 ha) is located in southeastern Montana (Carter County; lat $45^{\circ} 53^{\prime} \mathrm{N}$, long $104^{\circ} 21^{\prime} \mathrm{W}$ ) and is privately owned and managed for cattle grazing. The area is characterized by a semi-arid continental climate with relatively long, cold winters $\left(-6^{\circ} \mathrm{C}\right.$ long-term average low temperature) and summer conditions typified by frequent hot days and cool nights $\left(20^{\circ} \mathrm{C}\right.$ long-term average high temperature; Vanderhorst et al. 1998). The majority of the precipitation, recorded in Ekalaka, Montana, located $15 \mathrm{~km}$ west of the study site, comes in late spring and early summer (Western Regional Climate Center 2009). The most recent 30-yr average precipitation (1971-2000) is $438 \mathrm{~mm}$ while the 111-yr average (1896-2007) is $379 \mathrm{~mm}$. Total precipitation recorded for 1999 and 2005 was $49 \%$ and $16 \%$ above the $30-y r$ average, respectively, while 2002 and 2004 were, respectively, $31 \%$ and $38 \%$ below the 30 -yr average. Total precipitation recorded for the remaining years approximated the $30-y r$ average. Vegetation of the area is typical mixed-grass prairie of the northern Great Plains characterized by western wheatgrass (Pascopyrum smithii [Rydb.] A. Löve), blue grama (Bouteloua gracilis [Willd. ex Kunth] Lag. ex Griffiths), needle-and-thread (Hesperostipa comata [Trin. \& Rupr.] Barkworth), prairie junegrass (Koeleria macrantha [Ledeb.] Schult.), and threadleaf sedge (Carex filifolia Nutt.; MacCracken et al. 1983; Vanderhorst et al. 1998). The study site also contains extensive stands of woodlands dominated by Pinus ponderosa Laws.

\section{Biological Control Agents}

Thirty-two flea beetle (Aphthona spp.) release plots and 20 nonrelease were established in 1998 on scattered patches of leafy spurge. The area of the patches selected for study was estimated for those patches $\leq 46 \mathrm{~m}$ in diameter $\left(\leq 1661 \mathrm{~m}^{2}\right)$ by pacing the long and short axes of the patch (Butler et al. 2006). Thirty-nine patches met this criterion and had an average size of $1072 \mathrm{~m}^{2}$ (range $=408 \mathrm{~m}^{2}$ to $\left.1613 \mathrm{~m}^{2}\right)$. The diameter of the remaining 13 patches selected for plot placement was $>46 \mathrm{~m}\left(>1661 \mathrm{~m}^{2}\right.$ in area). The average distance between the center of each release plot and the center of its nearest nonrelease neighbor, measured using a geographic information system, was $377 \mathrm{~m}$ (range $=100 \mathrm{~m}$ to $934 \mathrm{~m}$; Butler et al. 2006). Attrition from a variety of land management activities (grazing, logging, and road construction) over the 9-yr period reduced the number of plots that could be sampled and analyzed. At the end of the experiment in 2006, 23 release and 11 nonrelease plots remained. Each plot was permanently marked by primary and secondary markers located in the center of the infested patch. In late June 1998, approximately 3000 black and 3000 brown flea beetles were released at the primary marker on all release plots. See Butler et al. (2006) for detailed description. 


\section{Vegetation Change}

Our general overarching hypothesis was that there would be little to no recovery of the vegetation to the "preinvasion" community structure and composition following successful suppression of leafy spurge. Plant community structural changes were evaluated using absolute values of total foliar cover, differences in absolute total cover between successive sampling dates for species grouped by origin (native vs. nonnative), and relative cover values organized by plant functional types (native forbs, native upland sedges, native grasses, and non-native species). Compositional changes were evaluated using species counts along with relative cover to estimate richness and species diversity, and using absolute species cover values in cluster analysis and indicator species analysis. Cluster analysis was used to develop a treatment (release, nonrelease, and noninfested) and time (sample year) classification that was subsequently used to calculate indicator values (IVs) for species in each classification group using Indicator Species Analysis (Dufrêne and Legendre 1997). This approach allowed us to evaluate the concentration of species abundance among release, nonrelease, and noninfested plots over time so that the performance of individual native and non-native species could be contrasted.

Plot vegetation was evaluated mid-June to early July of each year from 1998 through 2006, except 1999 when the vegetation was not sampled. Additionally, new plots were randomly located in areas not infested by leafy spurge (termed noninfested) in 2003 (20 plots), 2005 (15 plots), and 2006 (15 plots) but had physical and plant community features similar to infested plots. Plots were classified as noninfested if major native plant species were similar to infested plots, visible infestations of leafy spurge were at least $60 \mathrm{~m}$ from the plot, no leafy spurge stem residue was visible within the plots, and no flea beetles were present.

A reference line was established perpendicular to the slope at each sample plot (release, nonrelease, and noninfested) with the permanent marker, or temporary marker in the case of noninfested plots, serving as the center. Ten transects, in wagon-wheel fashion (five upslope and five downslope), were placed at 30-degree intervals with the first transect beginning 30 degrees from the reference line. Foliar cover of all plant species was estimated in each plot using $11,0.10 \mathrm{~m}^{2}(20 \times$ $50 \mathrm{~cm}$ ) quadrats. One quadrat was placed within $1 \mathrm{~m}$ of the permanent marker while each of the remaining 10 quadrats were placed approximately $2.5 \mathrm{~m}$ from the marker along each transect for a total of 11 quadrats per plot. This concentrated samples within the "halo" of control, a patch of dead leafy spurge stem that extends radially from the release point (Kalischuk et al. 2004).

\section{Data Analysis}

Foliar cover was estimated by placing each species occurring in the quadrat into one of six cover classes $(1=0-5 \%, 2=6-$ $25 \%, 3=26-50 \%, 4=61-75 \%, 5=76-95 \%$, and $6=95-$ $100 \%$; Daubenmire 1959). The mid-point of each cover class was used to calculate average foliar cover for each species recorded on each plot. After calculating mean foliar cover of leafy spurge for release and nonrelease plots, leafy spurge was then excluded from all other analyses. The total number of species recorded per plot and their relative cover values were used to estimate species richness $(\mathrm{R})$ per plot and to calculate a Shannon-Weiner Diversity Index $\left(\mathrm{H}^{\prime}\right)$. Individual plot values of $\mathrm{R}$ and $\mathrm{H}^{\prime}$ were then averaged for each treatment (release, nonrelease, and noninfested). Total cover for each quadrat was estimated by summing individual species cover values; consequently, foliar cover could be greater than $100 \%$ because of canopy overlap. Cover was also summed by quadrat based on origin (native vs. non-native) and by plant functional types that included native forbs, native dry-land sedges, native grasses, and non-native species. Mean relative cover was then calculated for the four plant functional types. Non-native species included introduced and naturalized species, except leafy spurge, as determined from PLANTS database, as were taxonomic names (USDA, Natural Resources Conservation Service 2009). Fifteen species were identified as non-native in this context and included Agropyron cristatum (L.) Gaertn., Bromus inermis Leyss. subsp. inermis, B. arvensis L., B. tectorum L., Camelina microcarpa Andrz. ex DC., Cirsium arvense (L.) Scop., Convolvulus arvensis L., Descurainia sophia (L.) Webb ex Prantl, Hyoscyamus niger L., Lactuca serriola L., Melilotus officinalis (L.) Lam., Poa compressa L., P. pratensis L., Taraxacum officinale F. H. Wigg., and Tragopogon dubius Scop. The two rhizomatous non-native species of bluegrass common to the area were grouped by genus (Poa pratensis and Poa compressa $=$ Poa spp.) and identified separate from the cespitose native Poa secunda. Further, all upland sedges were grouped as Carex spp. except Carex filifolia Nutt.

Annual changes in the contributions of native vs. non-native to total foliar cover were estimated by calculating the mean difference in cover from previous year values except 2000, which is the difference between 2000 and 1998. Pearson correlation coefficients were calculated for native and nonnative species for each sample year using foliar cover.

Differences in mean leafy spurge cover, mean $\mathrm{R}$, mean $\mathrm{H}^{\prime}$, mean total absolute foliar cover, and mean relative cover by plant functional type among sample years within noninfested treatments were evaluated using multi-response permutation procedures (Mielke and Berry 2001). The technique was also used to compare the same mean values among release, nonrelease, and noninfested plots within the 2003, 2005, and 2006 sample years. When the procedure detected a significant difference $(\alpha \leq 0.05)$, multiple comparisons were computed using the Peritz closure method (Petrondas and Gabriel 1983).

We conducted a hierarchical cluster analysis using the total number of species recorded within release, nonrelease, and noninfested treatments (93 species) for each year using PCORD (McCune and Mefford 2006; Sørenson's distance measure on mean foliar cover with flexible beta clustering strategy, $\beta=-0.25$ ) as a chronological and treatment classification and as prelude to the indicator species analysis. The resulting dendrogram was subjectively pruned at approximately $70 \%$ of the information remaining, which yielded seven clusters. Indicator species analysis (Dufrêne and Legendre 1997) was then conducted on all of the plots sampled throughout the study period (381 total plots for the three treatments over the $9 \mathrm{yr}$ of the study) grouped by the seven clusters using PC-ORD (McCune and Mefford 2006). Mean foliar cover for each species within a plot was used to estimate the within-cluster group mean abundance of each species. 
Relative abundance was then calculated by dividing mean abundance for each species within a group by the sum of group means. The frequency of occurrence for each species within each group was used as a measure of species constancy in a particular group (McCune and Grace 2002). An IV for each species for each of the seven groups, expressed as a percentage, was then calculated by multiplying relative abundance and frequency. IVs range from zero (no indication) to 100 (perfect indication) and both relative abundance and frequency must be high for the IV to be high. The statistical significance $(\alpha \leq 0.05)$ of the highest IV $\left(\mathrm{IV}_{\max }\right)$ for a given species across groups was evaluated using Monte Carlo simulation (5000 randomized runs). Species with significant $I_{\text {max }}$ values $\geq 25$ were then selected to serve as indicator species for that group.

We evaluated our prediction regarding the influence of soil fertility on patterns of vegetation dynamics by collecting soil samples during the 1999 field season from randomly selected release plots (16 plots) and nonrelease plots (12 plots). Each sample consisted of 10 cores (approximately $225 \mathrm{~cm}^{3}$ ) taken from the top $5 \mathrm{~cm}$ of soil that were thoroughly mixed before collecting a subsample that was analyzed for percent organic matter, cation exchange capacity, $\mathrm{K}, \mathrm{Na}, \mathrm{Ca}$, and $\mathrm{P}$ (meq/ $100 \mathrm{~g}), \mathrm{Mg}$ and $\mathrm{NO}_{3}-\mathrm{N}(\mathrm{mg} / \mathrm{kg}), \mathrm{pH}$, and percent saturation. The dominant gradients in soil characteristics among plots were extracted with Principal Component Analysis (PCA). A second matrix was constructed using mean foliar cover values for leafy spurge, and Poa spp. for 1998 and for 2005 and 2006 (averaged), and the combined cover of the major native grass species (western wheatgrass, blue grama, needle-and-thread, and prairie junegrass) averaged over 2005 and 2006. Pearson correlation coefficients were calculated between foliar cover and axis scores produced from the ordination.

\section{RESULTS}

Mean foliar cover of leafy spurge (Fig. 1a) and total foliar cover of the resident vegetation, excluding leafy spurge (Fig. 1b), were similar between release and nonrelease plots at the start of the experiment in $1998(P>0.05)$. Compared to 1998 prerelease values, significant reductions in foliar cover of leafy spurge were first recorded for release plots in 2000. Flea beetles dispersed naturally to nonrelease plots from release plots and from other releases on or near the ranch that were not part of our study. By 2001, foliar cover of leafy spurge on nonrelease plots was significantly less than 1998. Leafy spurge cover averaged less than $10 \%$ on release plots by 2001 and by 2004 for nonrelease plots. From 2004 through 2006, leafy spurge cover averaged $80 \%$ to $90 \%$ less than 1998 values.

Compared to 1998 values, total plot cover contributed by the resident vegetation, excluding leafy spurge, on release plots increased 33\% $(P \leq 0.05)$ by 2001 (Fig. 1b) while total cover on nonrelease plots changed little during the same time period. Mean cover values on release and nonrelease plots decreased significantly during the dry conditions of 2002 followed by steady increases through 2005. In 2003 mean cover recorded on noninfested plots was $54 \%$ greater than release plots and $147 \%$ greater than nonrelease plots $(P \leq 0.05)$. Total cover values recorded in 2006 on release and nonrelease plots was

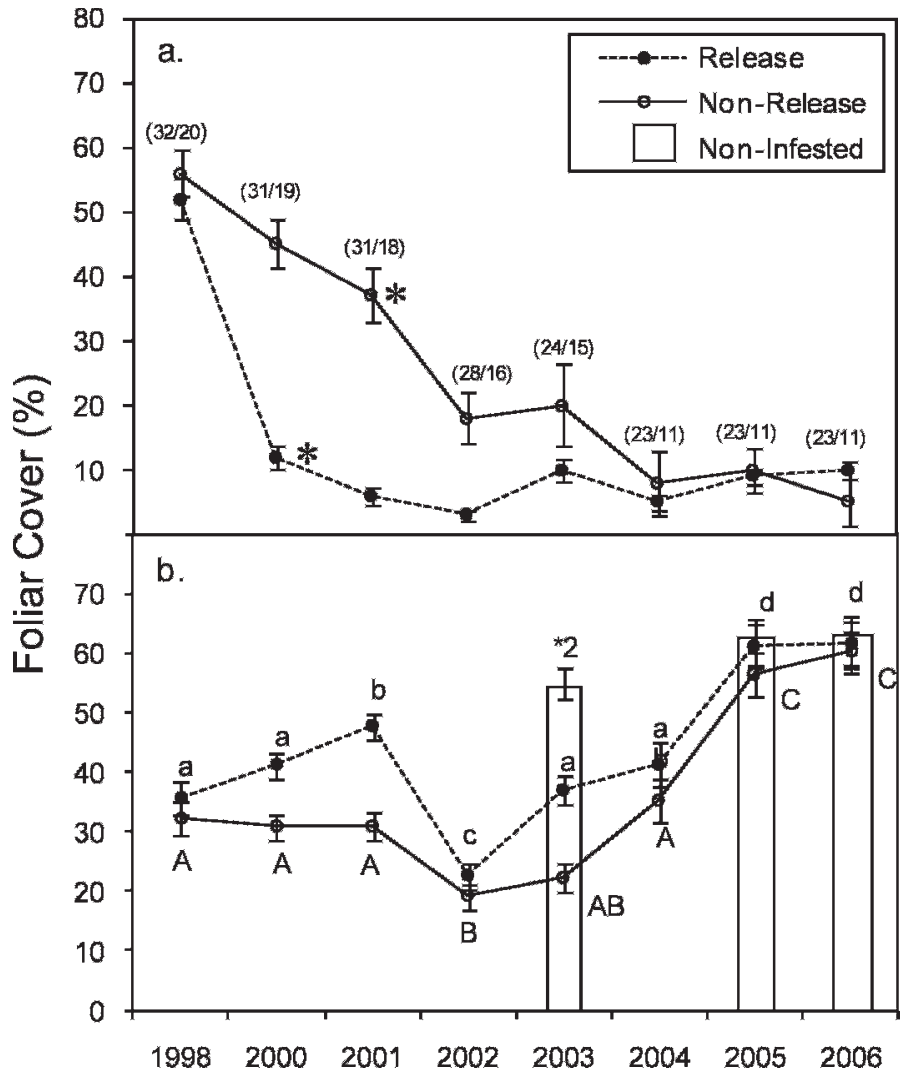

Figure 1. Mean foliar cover ( $\pm \mathrm{SE})$ for a, leafy spurge ( ${ }^{*}$ indicates first date of significant difference from 1998 mean values), and $\mathbf{b}$, mean total foliar cover of resident vegetation excluding leafy spurge (means among years within treatments of release, nonrelease, and noninfested followed by the same letter are similar, $P>0.05)$. *2 indicates significant difference between release, nonrelease, and noninfested plots $(P \leq 0.05)$. Number in parentheses indicates number of plots (release/ nonrelease).

$66 \%$ and $88 \%$ greater than 1998 values, and similar to noninfested plots in 2005 and $2006(P>0.05)$.

The majority of the change observed in total foliar cover between 1998 and 2000 for release plots can be attributed to increases in non-native plants and decreases in native plants (Fig. 2a). Within nonrelease plots, increases in non-native species cover were offset by almost equal decreases in native species cover for the first $3 \mathrm{yr}$ of the study (Fig. 2b). Much of the change that occurred in total cover for 2002 in release and nonrelease plots can be attributed to decreases in non-native species. Conversely, non-native species accounted for much of the increases in total cover that were observed in 2003 and 2005.

There was no correlation between non-native species cover and native species cover for both release and nonrelease plots at the beginning of the experiment in 1998 (Fig. 3). However, with the exception of 2006, significant negative correlations were recorded for release plots during years when the contribution of non-native species to total cover was greater than or equal to the contribution of native species (see Fig. 2a). Native and non-native species cover on nonrelease plots was correlated only during 2005 and 2006. Significant negative correlations generally coincided with years when annual 


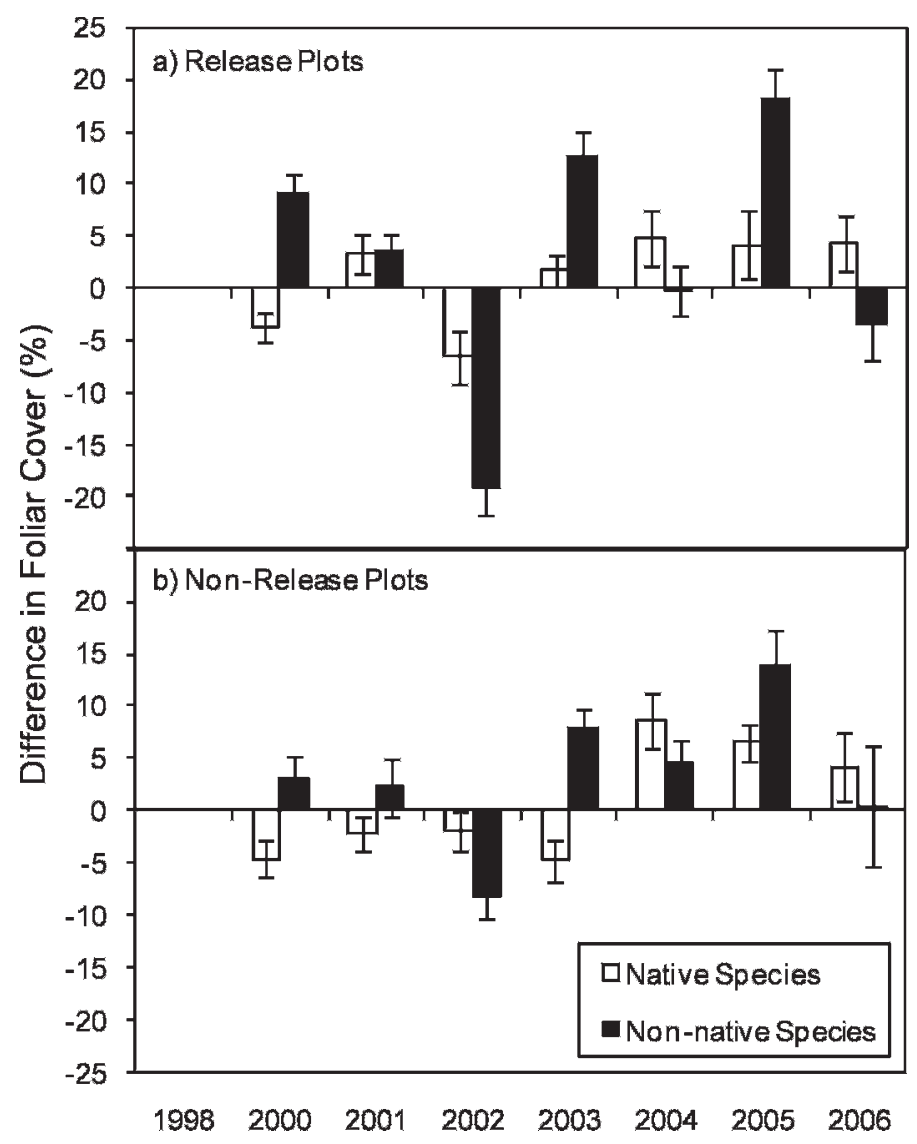

Figure 2. Mean difference $( \pm \mathrm{SE})$ in foliar cover from previous year estimates (except for 2000, which represents the difference between 1998 and 2000) for a, release and $\mathbf{b}$, nonrelease plots.

precipitation was greater than or equal to the $30-y r$ average. In contrast, no significant correlations were observed in release and nonrelease plots in 2002 and 2004 when precipitation was $31 \%$ and $38 \%$ below the 30 -yr average.

With a few exceptions likely related to precipitation patterns, the relative contributions of native forbs, native upland sedges, and native grasses were consistent between release plots and nonrelease plots and among years $(P>0.05$; Figs. $4 a-4 d)$. Native forbs and sedges collectively made up $25 \%$ to $29 \%$ of total vegetation cover on release and nonrelease plots at the beginning of the study in 1998 and at the end of the study in 2006. Relative cover values of forbs recorded on noninfested plots were $52 \%$ greater than release and nonrelease plots $(P \leq 0.05)$ in 2003 , and $60 \%$ greater than release plots $(P \leq 0.05)$ and $39 \%$ greater than nonrelease plots in 2005 $(P>0.05)$. The relative contribution of sedges increased significantly in 2002 compared to 2001. Sedge cover in noninfested plots was generally similar to release and nonrelease plots in 2003, 2005, and 2006, with the exception of 2005 when noninfested values were about $100 \%$ greater than release plots $(P \leq 0.05)$.

Native grasses and non-native species were the largest contributors to total vegetation cover on release and nonrelease plots throughout the study (Figs. $4 \mathrm{~b}$ and $4 \mathrm{~d}$ ). Relative contribution of native grasses in noninfested plots was consistently greater than release and nonrelease plots $(P \leq 0.05)$ while values for non-native species was consistently lower $(P \leq 0.05)$. Although values were statistically similar among years for release and nonrelease plots, relative foliar cover of native grasses in 2006 was 23\% to 30\% less than 1998 values (Fig. 4b). The relative contribution of non-native species ranged from a low of $39 \%$ in 2002 to a high of about $66 \%$ in 2005 (Fig. 4d). Poa spp. were the largest contributors to the total absolute cover of the non-native group averaging $84 \%$ $(\mathrm{SD}=6.9 ; n=16)$ across treatments and sample years (data not shown). Relative cover of non-native species on release and nonrelease plots was from three times to an order of magnitude greater than values recorded on noninfested plots in 2003, 2005, and 2006.

Mean $\mathrm{H}^{\prime}$ were similar among years for release and nonrelease plots, and between release and nonrelease plots for 2003, 2005, and 2006 (Fig. 5a). Mean $\mathrm{H}^{\prime}$ in noninfested plots was significantly greater than release and nonrelease plots in 2003 and 2005, and greater than release plots in 2006. Mean

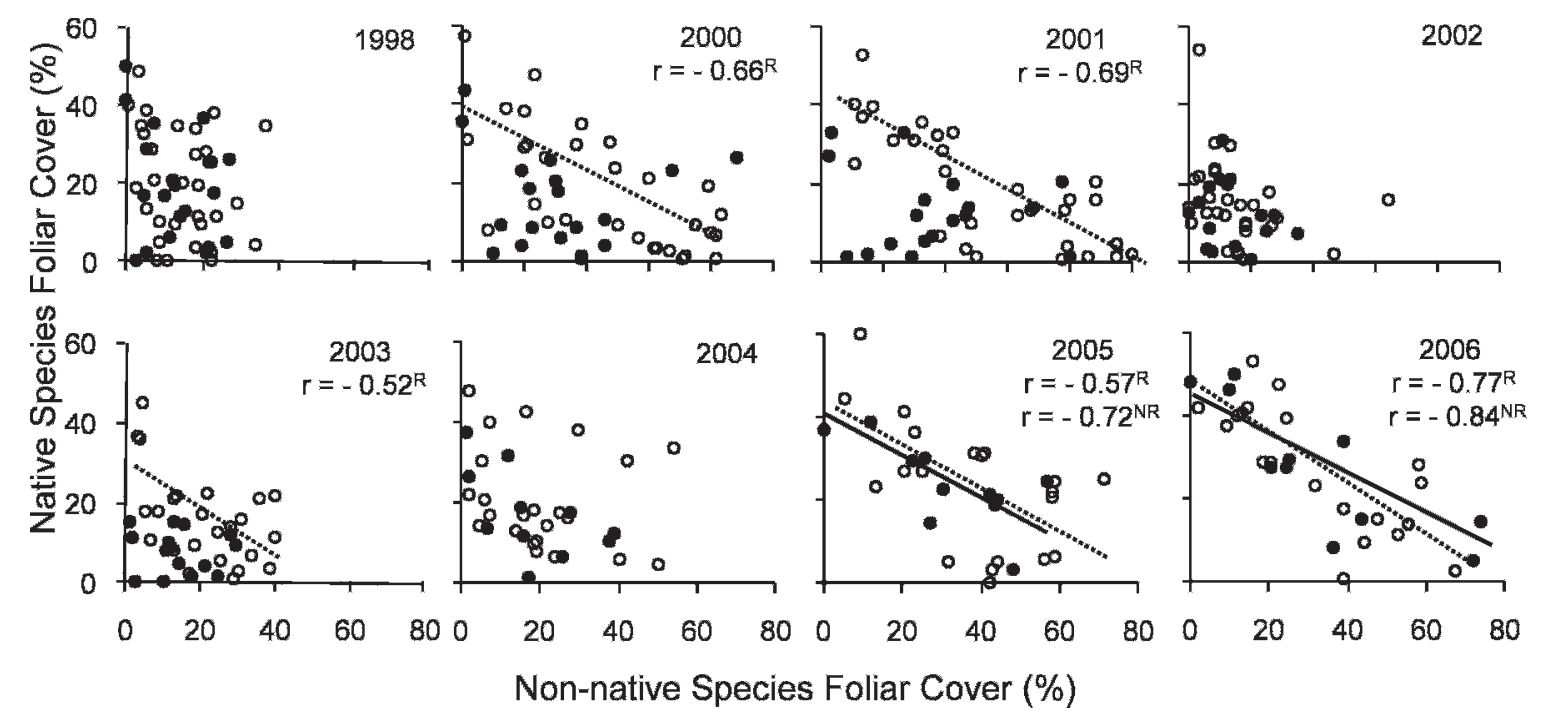

Figure 3. The relationship between native species foliar cover and non-native species foliar cover on release (open circle, dashed line) and nonrelease plots (closed circle, solid line; correlation coefficients are provided when $P \leq 0.05$ ). 

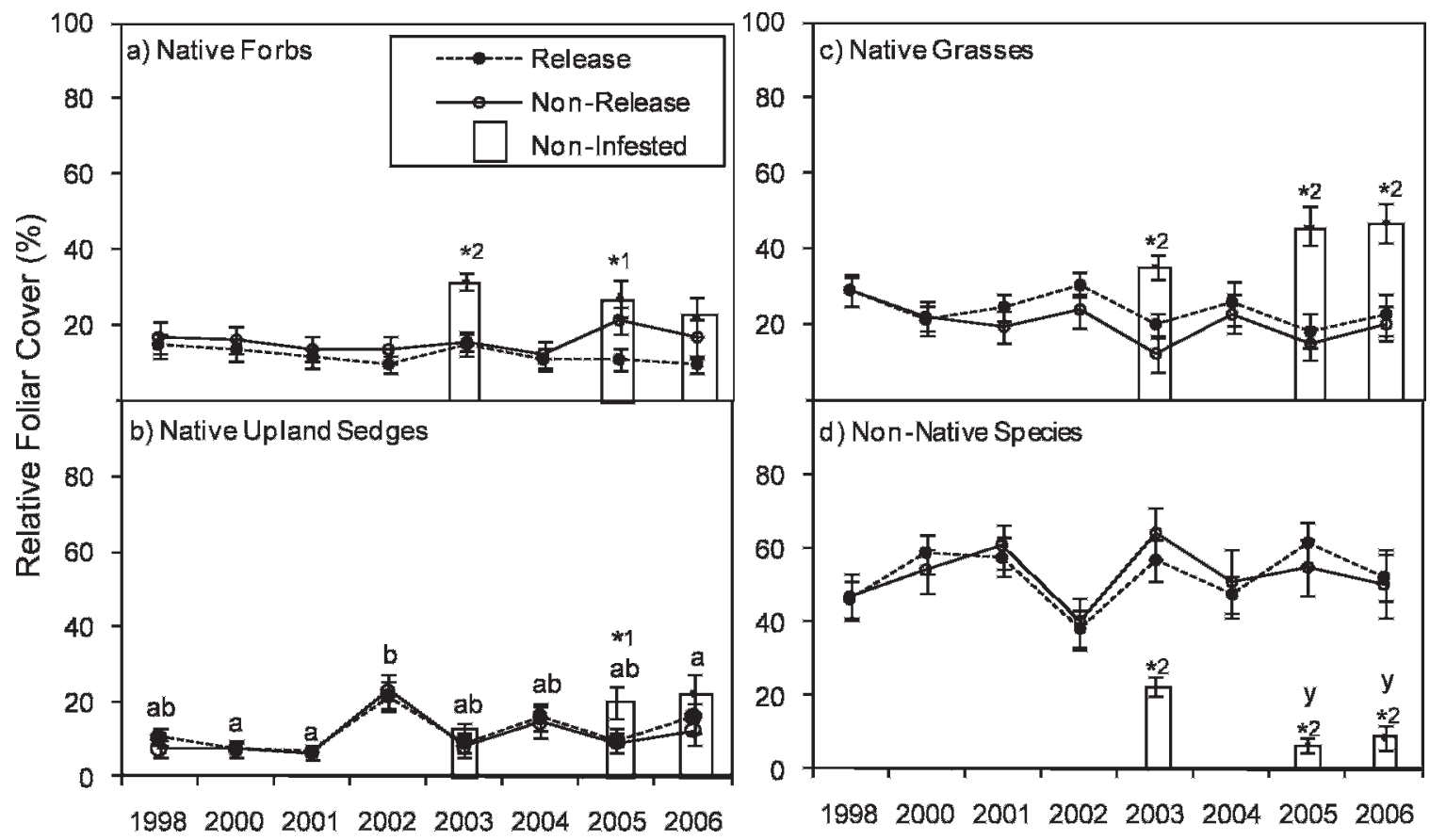

Figure 4. Mean relative foliar cover ( $\pm \mathrm{SE}$ ) of the major plant functional types (a, native forbs, $\mathbf{b}$, native grasses, $\mathbf{c}$, native upland sedges, and $\mathbf{d}$, non-native species) within release, nonrelease, and noninfested plots. Foliar cover means among years within treatments followed by the same letter are similar $(P>0.05)$. ${ }^{*} 1$ indicates different means $(P \leq 0.05)$ between noninfested plots and release plots and ${ }^{*} 2$ indicates different means between noninfested and release and nonrelease plots.

$\mathrm{R}$, like mean diversity values, did not differ among years for release and nonrelease plots (Fig. 5b); however, unlike diversity values, mean $\mathrm{R}$ was similar among noninfested, release, and nonrelease plots for the 2005 sample.

With the number of groups arbitrarily established at 7 , indicator species analysis was conducted for each step of the hierarchical structure produced by the cluster analysis (Fig. 6). The first division in the analysis (clusters =2) contrasts noninfested plots with infested plots (release and nonrelease). With an IV of 83 , Poa spp. (primarily P. pratensis) were the major species group for the vast majority of release and nonrelease plots, and persisted at relatively high levels throughout several of the subsequent divisions. The relatively dry conditions of 2000, 2002, and 2004 produced a distinctive cluster that could be further subdivided based on the response of the vegetation to the conditions of 2002. Release and nonrelease plots were consistently grouped together by year except for the last division, which separated the 2003, 2005, and 2006 sample years into the two treatments. No species met the criteria to serve as an indicator species (IV $\geq 25$ and $P \leq 0.05$ ) for the release and nonrelease plots sampled in 1998, 2001, and 2002, and for nonrelease plots in 2003, 2005, and 2006 suggesting considerable homogeneity among those plots. In contrast, noninfested plots were characterized by a wide variety of species with high IVs. For several species, IVs increased significantly when the noninfested plots were clustered by year (e.g., Collomia linearis Nutt., Aristida purpurea Nutt., Achillea millefolium L., and others for 2003). The more widespread species tended to persist as plots were divided (e.g., blue grama, prairie Junegrass, needle-andthread, and prairie sagewort [Artemisia frigida Willd.]), although their individual IVs decreased.
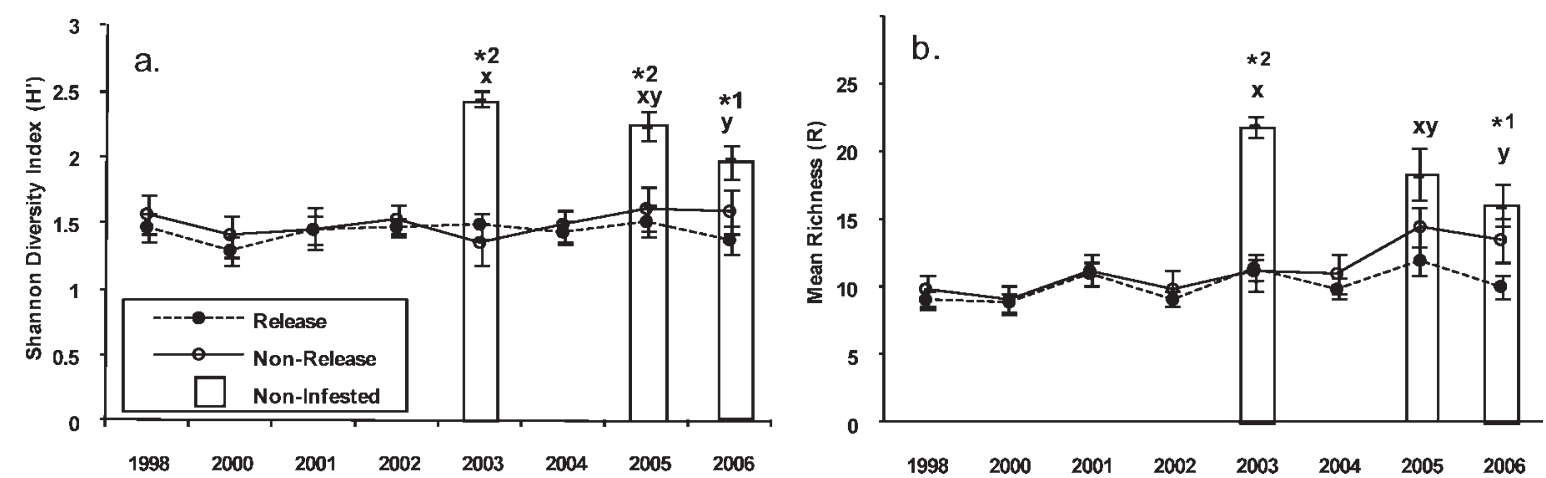

Figure 5. Plot means $( \pm S E)$ by treatment for a, diversity $\left(H^{\prime}\right)$ and $\mathbf{b}$, species richness $(R)$. Means among years within release and nonrelease plots are similar $(P>0.05)$. ${ }^{*} 1$ indicates different means $(P \leq 0.05)$ between noninfested plots and release plots and ${ }^{*} 2$ indicates different means between noninfested and release and nonrelease plots. 


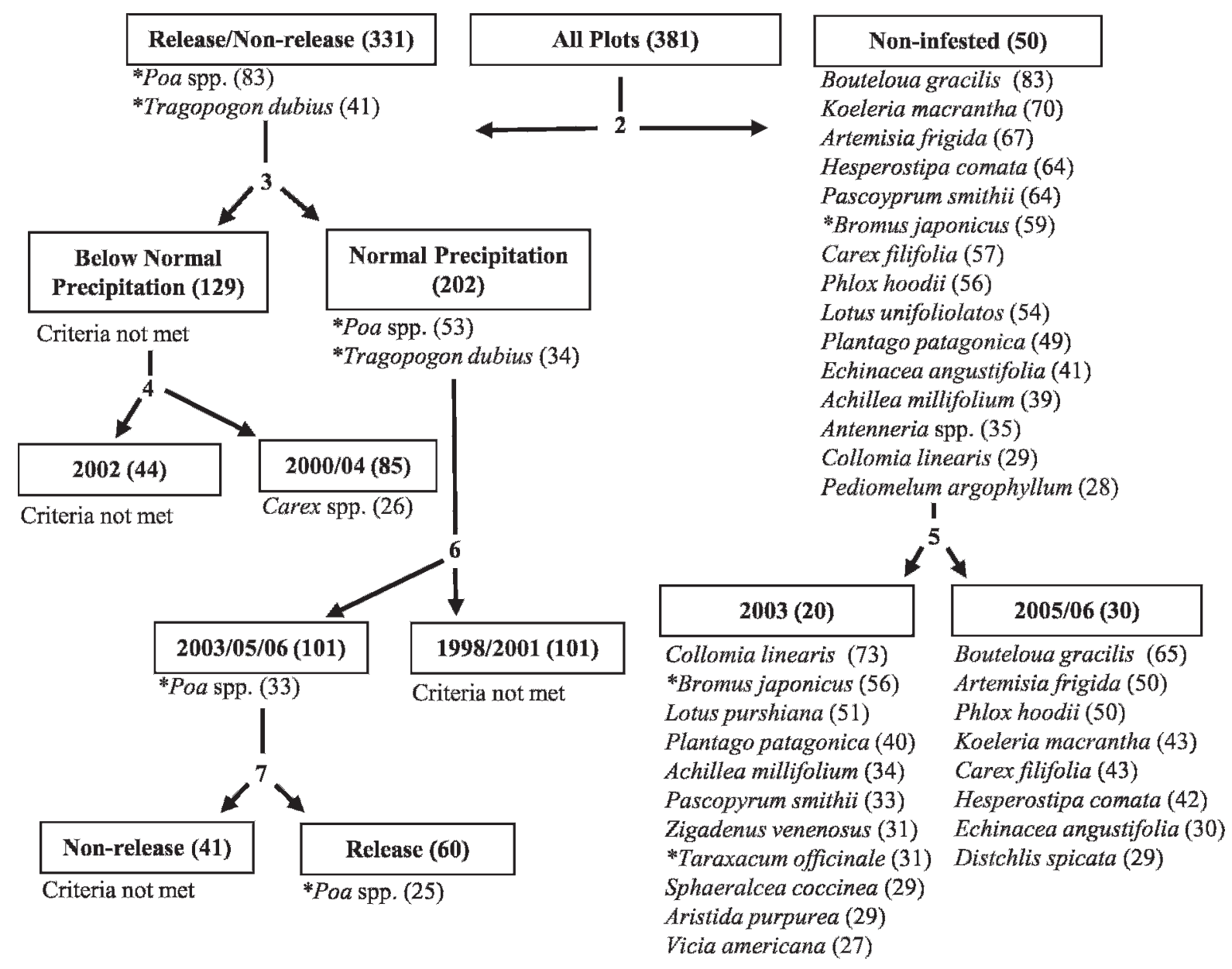

Figure 6. Treatment clusters and associated significant indicator species $(P \leq 0.05)$ with indicator values in parenthesis. Numbers in parentheses within boxes are the number plots analyzed in that cluster. * indicates non-native species.

The cumulative proportion of variance in soil characteristics captured by the first two PCA axes was $86 \%$ with three variables exhibiting eigenvectors greater than 0.30 (Table 1). Percent saturated cations were heavily loaded on Axis 1 while $\mathrm{NO}_{3}-\mathrm{N}$ had high loadings for Axis 2. Foliar cover values for leafy spurge were positively correlated with Axis 1 PCA scores for the 28 plots sampled in $1998(P \leq 0.05$, Fig. 7a) but not for the 20 plots sampled in 2005 and 2006 (data not shown). The opposite pattern was observed for Poa spp. where significant positive correlations were observed at the end of the experiment (average of the 2005/2006 foliar cover values) but not for $1998(P>0.05)$. In contrast to the positive relationships exhibited by the non-native species and the Axis 1 scores, the combined foliar values for the three major native grass species were negatively correlated to Axis 1 (Fig. 7b).

\section{DISCUSSION}

Because of the aggressive nature of invasive plants such as leafy spurge, the primary objective of management and research has, understandably, focused almost exclusively on the short-term goal of suppression with limited attention given to restoration of the altered community (D'Antonio and Meyerson 2002). Making repeated observations of the same area over time is a relatively direct, unambiguous method of documenting vegetation dynamics in response to significant reductions in the target weed. However, fully interpreting responses in the resident vegetation in our study after successfully suppressing populations of leafy spurge is challenging for several reasons. First, the ecological condition of each site prior to invasion is unknown. To help address this issue, we used nearby noninfested plots with similar physical and biological characteristics as surro-

Table 1. Principle component loadings for the first two axes (SAT, saturated paste; OM, organic matter; and CEC, cation exchange capacity). Loadings greater than 0.30 are in boldface.

\begin{tabular}{lcccrcrrrrrr}
\hline & $\%$ variation & $\mathrm{SAT}$ & $\mathrm{OM}$ & $\mathrm{NO}_{3}-\mathrm{N}$ & $\mathrm{Ca}_{3}$ & $\mathrm{CEC}$ & \multicolumn{1}{c}{$\mathrm{P}$} & $\mathrm{Mg}$ & $\mathrm{pH}$ & $\mathrm{Na}$ & $\mathrm{K}$ \\
\hline Axis 1 & 66.2 & $\mathbf{0 . 8 4}$ & 0.11 & $\mathbf{0 . 4 0}$ & 0.19 & 0.26 & 0.11 & 0.25 & -0.00 & -0.00 & 0.02 \\
Axis 2 & 19.5 & 0.22 & -0.02 & $\mathbf{- 0 . 8 3}$ & 0.24 & $\mathbf{0 . 4 1}$ & -0.09 & -0.05 & 0.03 & 0.03 & -0.00 \\
\hline
\end{tabular}



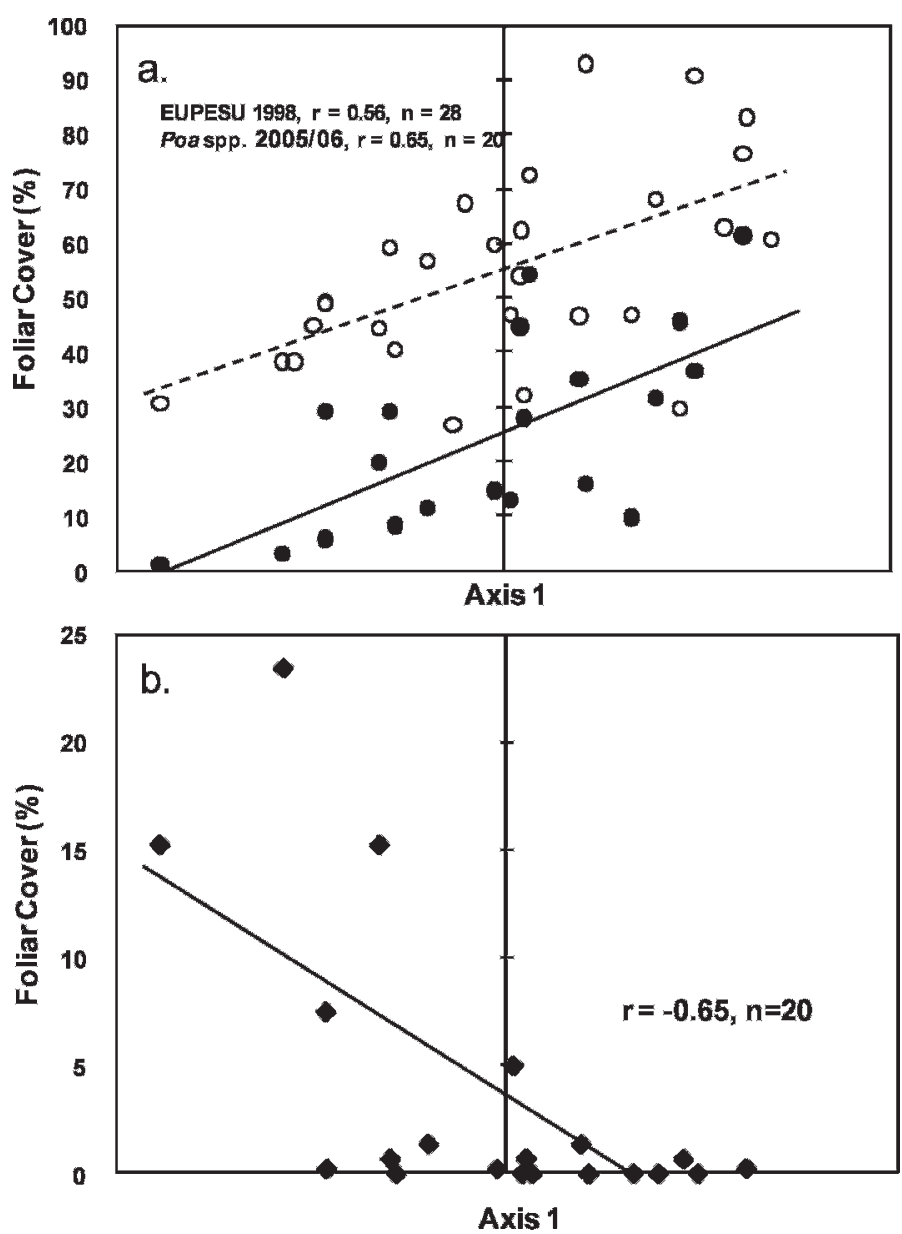

Figure 7. Relationships between Axis 1 scores generated from the principle component analysis representing a soil fertility gradient (see Table 1) and a, mean foliar cover of leafy spurge (EUPESU, open circles, dashed line) for 1998 and Poa spp. ( $P$. pratensis and $P$. compressa, solid circles, solid line) for 2005/2006 (averaged), and $\mathbf{b}$, mean foliar cover of the combined cover of three native grass species (Heterostipa comata, Koeleria macrantha, and Bouteloua gracilis).

gates for the preinfestation condition and as reference measures for the potential vegetation (Carson et al. 2008). Because of the wide ecological and geographic distribution of leafy spurge, we assumed that infested and noninfested sites were equally susceptible to invasion. Second, the natural dispersal of the biological control agents and unplanned releases by the land manager substantially decreased the value of the nonrelease plots as long-term reference points.

Recognizing these limitations, several general and specific patterns in vegetation dynamics were observed in relation to our hypotheses. The rapid reductions in leafy spurge dominance demonstrated on release plots produced a significant and simultaneous increase in total cover of the remaining resident species. Flea beetles dispersed, more or less naturally, to nonrelease plots (Butler et al. 2006) with reductions in leafy spurge occurring at slower rates compared to release plots. By the end of the experiment total foliar cover of the resident vegetation on release and nonrelease plots increased substantially and converged to values similar to noninfested plots. Native species collectively and consistently made up about
$40 \%$ of the total vegetative cover on release and nonrelease plots (Fig. 4) and included many of the same species identified as indicator species for noninfested plots (Fig 6). However, despite the relatively rapid and substantial increases in total foliar cover of the resident vegetation on infested plots (Fig. 1), the relative contributions of native species to total cover remained consistently lower than non-native species and lower than noninfested plots with no difference between release and nonrelease plots (Fig. 4). Further, we observed no change in species richness or diversity with the declining dominance of leafy spurge, a pattern also reported by Lesica and Hanna (2004) in north-central Montana. In contrast, Mico and Shay (2002) reported that species richness on flea beetle release sites tended to be higher than nonrelease sites in Canada. Because we detected no significant change in the plant community following suppression of leafy spurge, we accepted our first hypothesis that post-treatment vegetation would be dominated by functional groups and species that were able to persist throughout the infestation. For the duration of our study, the native plant community remained compositionally similar among release and nonrelease plots, but distinctly dissimilar to noninfested plots during the 2003, 2005, and 2007 sample years, supporting our second hypothesis.

Carson et al. (2008) described scenarios in which the native plant community may fail to recover, show a significant time lag, or re-assemble with a different set of species following successful biological control. Direct effect scenarios important to our study include 1) native source limitation and 2) novel weapons; indirect effects include 3) trophic shifts and 4) invasive engineering. A fifth scenario, associated species, is related to our third hypothesis and develops when co-occurring non-native species constitute the bulk of the replacement vegetation following suppression of the target invasive species, thus effectively preventing native vegetation from recovering. In our study, non-native species co-occurring with leafy spurge made up about $46 \%$ of the total cover of the resident vegetation cover on infested sites in 1998 and, with the exception of 2002 , averaged $57 \%$ throughout the remainder of the study (Fig. 4d).

Once established, strong invaders (sensu Ortega and Pearson 2005) such as leafy spurge may make the community more susceptible to invasion by other non-native species through their competitive impacts on native species (Vila and Weiner 2004; Maron and Marler 2008), especially under conditions of high resource availability and unnatural disturbance (Daehler 2003). Studies specific to leafy spurge tend to confirm that high diversity and abundance of non-native species are often associated with infestations of leafy spurge, especially in mesic environments (Larson et al. 2001; Butler and Cogan 2004; Samuel et al. 2008). The majority of the increases we observed in total cover from 1998 to 2006 were attributed to increases in non-native species to the extent that by the end of the study significant negative correlations developed between cover of native species and cover of non-native species (Fig. 3). Belcher and Wilson (1989) reported similar negative correlations between frequency of leafy spurge and frequency of several native species in a Manitoba mixed-grass prairie.

Non-native Poa spp. were minor components of our noninfested sites but were the largest contributors on infested sites (Fig. 6) with no obvious relationship to disturbance 
(overgrazing, logging activities, etc.) or physiographic situation. Mico and Shay (2002) reported that Kentucky bluegrass, along with leafy spurge and various sedge species, were the only species consistently found on all of their flea beetle release and nonrelease sites. In studies conducted in North Dakota, Kentucky bluegrass was found to persist in a variety of plant communities heavily infested with leafy spurge (Butler and Cogan 2004), and to increase when leafy spurge density was reduced (Lym and Kirby 1987). In a simulated defoliation study of leafy spurge, Kirby et al. (1997) reported that $67 \%$ to $80 \%$ of the total grass yield on infested, untreated sites consisted of Kentucky bluegrass. In that study, yields for both Kentucky bluegrass and total grass increased under all six defoliation treatments compared to untreated plots; however, the proportion of the total grass yields contributed by Kentucky bluegrass remained $64 \%$ to $80 \%$ under all defoliation treatments.

In our study, Poa spp. effectively replaced leafy spurge as the dominant non-native species, a trend enhanced by soil characteristics generally accepted as conditions favorable for plant productivity (Fig. 7a), supporting our third hypothesis and our prediction regarding the influence of soil fertility. Although how much of the replacement vegetation came from colonizing plants versus existing vegetation is unknown, the overall pattern tends to support the associated species scenario as described by Carson et al. (2008). A similar replacement situation was reported by Symstad (2004) for an Illinois sand prairie where Kentucky bluegrass increased significantly when the primary invasive species, trailing crownvetch (Coronilla varia L.), was suppressed with a herbicide, a response that was enhanced by elevated nitrogen conditions found within the treated trailing crownvetch patches.

Although we did not evaluate soil characteristics on noninfested plots, our results suggest that the abundance and composition of native and exotic species in our study varied along a gradient of soil conditions that influence plant productivity (Figs. 7a and 7b). In synthesizing published performance comparisons between native and invasive plants, Daehler (2003) found that low resource availability was the most common growing condition favoring native species over invasive species. On the more productive invaded sites in our study, patterns of abundance between native and non-native species were similar to that described by Macdougall et al. (2006). In that study, the number of native species declined with increasing soil depth while the dominance of invasive perennial grasses, including Kentucky bluegrass, increased. Less productive soils are not protected from invasion (Macdougall et al. 2006; Maron and Marler 2008); however, the less productive soil characteristics may be somewhat more stressful for Kentucky bluegrass and leafy spurge, but not for locally adapted native species (Daehler 2003). This may be an important factor in allowing for a certain level of co-existence (Price and Morgan 2007), a pattern that may become more pronounced with successful suppression of the target invasive species. Experiments designed to facilitate restoration of native species by directly manipulating nutrients (Huenneke et al. 1990; Cherwin et al. 2008) or by adding carbon to immobilize nitrogen (Blumenthal et al. 2003) tend to support the role of limited nutrients in supporting co-existence among native and non-native species.
Below normal precipitation may also be more stressful for the non-native species compared to the resident native species. For example, in 2002 and 2004 when precipitation was, respectively, $31 \%$ and $38 \%$ below the $30-y r$ average, native species appeared to be less negatively impacted, or possibly enhanced, compared to non-native species (Figs. 2a and 2b). Low water availability is an example of a strong environmental filter that simultaneously constrains and promotes species with similar key traits, i.e., groups of species with similar water-use efficiencies (see Funk et al. 2008).

Other scenarios described by Carson et al. (2008) likely contributed to the associated species scenario in influencing the low level of vegetation recovery we observed. Inadequate seed input by native species (native source limitation scenario) from surrounding areas or from persistent residents within leafy spurge-invaded sites (Butler and Cogan 2004) could severely limit potential recovery (Daehler 2003). However, Laufmann (2006) reported that $50 \%$ to $75 \%$ of the common native species within leafy spurge noninfested sites in North Dakota had seed present in infested or biologically controlled sites, suggesting that potential future establishment of native species from the seed bank may be adequate.

The presence of biochemical exudates (allelochemicals) released by invasive plants that interfere with germination, establishment, and growth of native species and disrupt soil microbial communities (novel weapons scenario) may be a driving force behind the success of a dominant weed (Callaway and Ridenour 2004). Evidence that leafy spurge exhibits allelopathic characteristics is sparse (Steenhagen and Zimdahl 1979), and studies are needed that specifically examine the residual effects of biochemically produced phytotoxins on vegetation recovery following control of the target weed. Trophic shifts are another potential scenario affecting vegetation recovery that occurs when the target or the associated invasive species interact with the biotic environment to influence native plant recovery (Carson et al. 2008). For example, Lym and Kirby (1987) reported that cattle grazing behavior was negatively impacted when leafy spurge stem densities were greater than $100 \cdot \mathrm{m}^{-2}$ and reducing stem densities below that level would increase the probability of livestock grazing (Kirby et al. 2000). The alteration of livestock grazing patterns following leafy spurge suppression may enhance the shift to a Kentucky bluegrass dominated community on more productive sites (Kauffman et al. 1983), although the total effect may be influenced by other constituent species (Evans et al. 2004).

Other potential shifts in the biotic community and possible interactions with the abiotic environment (invasive engineering scenario) related to aggressive plant invaders include alterations of the microarthopod community, symbiotic relationships such as between native plants and arbuscular mycorrhizal fungi, and litter decomposition rates (Pritekel et al. 2006). Although Pritekel et al. (2006) found no differences in mycorrhizal inoculum or litter decomposition rates between leafy spurge-infested and -noninfested plots in Rocky Mountain National Park (USA), they did show significantly higher soil microarthopod densities and higher densities of specific suborders of Acari in noninfested plots. Further, they reported that substrate losses of lignin, phosphorous, and trace elements from decomposing litter were less on some plots invaded by 
leafy spurge. Jordan et al. (2008) assessed the ability of leafy spurge to modify soil attributes to the extent that invasions may be self-facilitated or cross-facilitated (one invasive species facilitates the invasion of another invasive species). While these researchers found no evidence of self-facilitation by leafy spurge, they did report that soil modification by leafy spurge may facilitate the establishment of other non-native species (crested wheatgrass and smooth bromegrass in their study), while having an antagonistic effect on some native species. The collective evidence supports the potential for leafy spurge infestations to change the composition and function of the belowground community to the extent that the residual effects of the modifications may be facilitating the establishment and dominance of other non-native species, such as Poa spp., while impeding the ability of native species and communities to recover (Reinhart and Callaway 2006).

\section{MANAGEMENT IMPLICATIONS}

From a livestock production perspective, the replacement of leafy spurge by Poa spp. can be considered an improvement over the leafy spurge-infested condition. However, our results indicate that the potential replacement of leafy spurge by other aggressive exotic species is high, a pattern that is consistent with much of the available literature for other invasive plant species (Huffaker and Kennett 1959; Bush et al. 2007; but see Lesica and Hanna 2004; Barton et al. 2007). Our study was not designed to evaluate the long-term persistence of a plant community dominated by Poa spp.; however, the strong negative correlations that developed between cover of native species and cover of non-native species by the end of our study suggest that Poa spp., and possibly other non-native species, may continue to occupy these sites without active restoration. From a practical perspective, initiating invasive plant control under conditions of high potential for re-infestation or secondary invasion and low long-term financial commitment for repeated management and restoration requires careful risk assessment (Murphy et al. 2007; Rinella et al. 2009). Treating new infestations as soon as possible is the most economical approach to avoiding the long-term residual effects of large contributions to the seed bank, native species loss, and ecosystem modification. On older, established infestations, detailed pretreatment site evaluations that include information on site productivity, plant species composition and relative abundance, and current and future land-use will help managers anticipate and respond proactively to post-treatment conditions (Sheley et al. 1996).

\section{ACKNOWLEDGMENTS}

The authors wish to thank John Murphy and Matt Parker for assistance in data collection and Rudy King for assistance in statistical analysis. We thank Diane Larson, Justin Runyon, Beth Burkhart, and Mark Vedder for reviewing early drafts of the manuscript, and two anonymous reviewers for their comments and suggestions for improving the manuscript. We greatly appreciate the technical and logistical assistance provided by Chad Prosser throughout the study. The cooperation of ranchers Wes Allerdings, Ted and Virginia Baldick, and Leroy Schallenberger is very much appreciated.

\section{LITERATURE CITED}

Barton, J., S. V. Fowler, A. F. Gianotti, C. J. Winks, M. De Beurs, G. C. Arnold, and G. ForRester. 2007. Successful biological control of mist flower (Ageratina riparia) in New Zealand: agent establishment, impact and benefits to the native flora. Biological Control 40:370-385.

BelCher, J. W., AND S. D. WILSON. 1989. Leafy spurge and the species composition of a mixed-grass prairie. Journal of Range Management 42:172-175.

Blumenthal, D. M., N. R. Jordan, and M. P. Russelle. 2003. Soil carbon addition controls weeds and facilitates prairie restoration. Ecological Applications 13:605-615

Bush, R., T. Seastedt, and D. Buckner. 2007. Plant community response to the decline of diffuse knapweed in a Colorado grassland. Ecological Restoration 25:169-174.

Butler, J. L., And D. R. Cogan. 2004. Leafy spurge effects on patterns of plant species richness. Journal of Range Management 57:305-311.

Butler, J. L., M. S. Parker, and J. T. Murphy. 2006. Efficacy of flea beetle control of leafy spurge in Montana and South Dakota. Rangeland Ecology \& Management 59:453-461.

Callaway, R. M., and W. M. Ridenour. 2004. Novel weapons: invasive success and the evolution of increased competitive ability. Frontiers in Ecology and the Environment 2:436-443.

Carson, W. P., S. M. Hovick, A. J. Baumert, D. E. Bunker, and T. H. Pendergast. 2008. Evaluating the post-release efficacy of invasive plant biocontrol by insects: a comprehensive approach. Arthropod-Plant Interactions 2:77-86.

Cherwin, K. L., T. R. Seastedt, and K. N. Suding. 2008. Effects of nutrient manipulations and grass removal on cover, species composition, and invasibility of a novel grassland in Colorado. Restoration Ecology 17:818826.

Cornett, M. W., P. J. Bauman, and D. D. Breyfogle. 2006. Can we control leafy spurge? Adaptive management and the recovery of native vegetation. Ecological Restoration 24:145-150.

D’Antonio, C., and L. A. Meyerson. 2002. Exotic plant species as problems and solutions in ecological restoration: a synthesis. Restoration Ecology 10: 703-713.

DaEHLER, C. C. 2003. Performance comparisons of co-occurring native and alien invasive plants: implications for conservation and restoration. Annual Review of Ecology Evolution and Systematics 34:183-211.

Daubenmire, R. 1959. A canopy-coverage method of vegetational analysis. Northwest Science 33:43-64.

Denslow, J. S., And C. M. D’Antonio. 2005. After biocontrol: assessing indirect effects of insect releases: science and decision making in biological control of weeds: benefits and risks of biological control. Biological Control 35:307318.

Dufrene, M., and P. Legendre. 1997. Species assemblages and indicator species: the need for a flexible asymmetrical approach. Ecological Monographs 67:345-366

Evans, S. G., A. J. Pelster, W. C. Leininger, and M. J. Trlica. 2004. Seasonal diet selection of cattle grazing a montane riparian community. Journal of Range Management 57:539-545.

Funk, J. L., E. E. Cleland, K. N. Suding, and E. S. Zavaleta. 2008. Restoration through reassembly: plant traits and invasion resistance. Trends in Ecology \& Evolution 23:695-703.

Hansen, R. W., R. D. Richard, P. E. Parker, and L. E. Wendel. 1997. Distribution of biological control agents of leafy spurge (Euphorbia esula L.) in the United States: 1988-1996. Biological Control 10:129-142.

Huenneke, L. F., S. P. Hamburg, R. Koide, H. A. Mooney, and P. M. Vitousek. 1990. Effects of soil resources on plant invasion and community structure in Californian serpentine grassland. Ecology 71:478-491.

Huffaker, C. B., And C. E. Kennetr. 1959. A ten-year study of vegetational changes associated with biological control of klamath weed. Journal of Range Management 12:69-82.

Jordan, N. R., D. L. LaRSon, and S. C. Huerd. 2008. Soil modification by invasive plants: effects on native and invasive species of mixed-grass prairies. Biological Invasions 10:177-190. 
JosHI, A. 2008. Integrating flea beetles (Aphthona spp.) with herbicide and grasses for leafy spurge (Euphorbia esula) management. Weed Technology 22: 523-529.

Kalischuk, A. R., R. S. Bourchier, and A. S. McClay. 2004. Post hoc assessment of an operational biocontrol program: efficacy of the flea beetle Aphthona lacertosa rosenhauer (chrysomelidae: coleoptera), an introduced biocontrol agent for leafy spurge. Biological Control 29:418-426.

Kauffman, J. B., W. C. Krueger, and M. Vavra. 1983. Effects of late season cattle grazing on riparian plant-communities. Journal of Range Management 36:685-691.

Kirby, D. R., R. B. Carlson, K. D. Krabbenhoft, D. Mundal, and M. M. Kirby. 2000. Biological control of leafy spurge with introduced flea beetles (Aphthona spp.). Journal of Range Management 53:305-308.

Kirby, D. R., T. P. Hanson, K. D. Krabbenhoft, and M. M. Kirby. 1997. Effects of simulated defoliation on leafy spurge (Euphorbia esula) infested rangeland. Weed Technology 11:586-590.

Larson, D. L., P. J. Anderson, and W. Newton. 2001. Alien plant invasion in mixedgrass prairie: effects of vegetation type and anthropogenic disturbance. Ecological Applications 11:128-141.

Larson, D. L., and J. B. Grace. 2004. Temporal dynamics of leafy spurge (Euphorbia esula) and two species of flea beetles (Aphthona spp.) used as biological control agents. Biological Control 29:207-214.

Larson, D. L., J. B. Grace, and J. L. Larson. 2008. Long-term dynamics of leafy spurge (Euphorbia esula) and its biocontrol agent, flea beetles in the genus Aphthona. Biological Control 47:250-256.

Laufmann, J. A. 2006. Biological control affects native vegetation and recovery potential in Theodore Roosevelt National Park, North Dakota. Fort Collins, CO, USA: Colorado State University. $155 \mathrm{p}$.

Lesica, P., and D. Hanna. 2004. Indirect effects of biological control on plant diversity vary across sites in Montana grasslands. Conservation Biology 18:444-454.

LYM, R. G. 1998. The biology and integrated management of leafy spurge (Euphorbia esula) on North Dakota rangeland. Weed Technology 12:367-373.

LYM, R. G., AND D. R. KIRBY. 1987. Cattle foraging behavior in leafy spurge (Euphorbia esula)-infested rangeland. Weed Technology 1:314-318.

LYM, R. G., AND C. G. MESSERSMitH. 1985. Leafy spurge control and improved forage production with herbicides. Journal of Range Management 38:386-391.

Lym, R. G., And J. A. Nelson. 2000. Biological control of leafy spurge (Euphorbia esula) with Aphthona spp. along railroad right-of-ways. Weed Technology 14:642-646.

Lym, R. G., AND J. A. Nelson. 2002. Integration of Aphthona spp. flea beetles and herbicides for leafy spurge (Euphorbia esula) control. Weed Science 50:812-819.

MacCracken, J. G., D. W. Uresk, and R. M. Hansen. 1983. Plant community variability on a small area in southeastern Montana. Great Basin Naturalist 43:660-668.

MacDougall, A. S., J. Boucher, R. Turkington, and G. E. Bradfield. 2006. Patterns of plant invasion along an environmental stress gradient. Journal of Vegetation Science 17:47-56.

Maron, J. L., and M. Marler. 2008. Field-based competitive impacts between invaders and natives at varying resource supply. Journal of Ecology 96:1187-1197.
McCune, B., and J. B. Grace. 2002. Analysis of ecological communities. Gleneden Beach, OR, USA: MjM Software Design. 300 p.

McCune, B., And M. J. MefFord. 2006. PC-ORD. Multivariate analysis of ecological data. Version 5.19. Gleneden Beach, OR, USA: MjM Software Design.

Mico, M. A., AND J. M. SHAY. 2002. Effect of flea beetles (Aphthona nigriscutis) on prairie invaded by leafy spurge (Euphorbia esula) in Manitoba. Great Plains Research 12:167-184.

Mielke, P., JR., And K. Berry. 2001. Permutation methods: a distance function approach. New York, NY, USA: Springer-Verlag. 352 p.

Murphy, S. D., J. Flanagan, K. Noll, D. Wilson, and B. Duncan. 2007. How incomplete exotic species management can make matters worse: experiments in forest restoration in Ontario, Canada. Ecological Restoration 25:85-93.

Ortega, Y. K., and D. E. Pearson. 2005. Weak vs. strong invaders of natural plant communities: assessing invasibility and impact. Ecological Applications 15:651-661.

Petrondas, D. A., and K. R. Gabriel. 1983. Multiple comparisons by rerandomization tests. Journal of the American Statistical Association 78:949-957.

Price, J. N., and J. W. Morgan. 2007. Vegetation dynamics following resource manipulations in herb-rich woodland. Plant Ecology 188:29-37.

Pritekel, C., A. Whittemore-Olson, N. Snow, and J. C. Moore. 2006. Impacts from invasive plant species and their control on the plant community and belowground ecosystem at Rocky Mountain National Park, USA. Applied Soil Ecology 32:132-141.

Reinhart, K. 0., and R. M. Callaway. 2006. Soil biota and invasive plants. New Phytologist 170:445-457.

Rinella, M. J., B. D. Maxwell, P. K. Fay, T. Weaver, and R. L. Sheley. 2009. Control effort exacerbates invasive-species problem. Ecological Applications 19:155-162.

Samuel, L. W., D. R. Kirby, J. E. Norland, and G. L. Anderson. 2008. Leafy spurge suppression by flea beetles in the Little Missouri drainage basin, USA. Rangeland Ecology \& Management 61:437-443.

Selleck, G. W., C. Frankton, and R. T. Coupland. 1962. Leafy spurge in Saskatchewan. Ecological Monographs 32:1-29.

Sheley, R. L., T. J. Svejcar, And B. D. Maxwell. 1996. A theoretical framework for developing successional weed management strategies on rangeland. Weed Technology 10:766-773.

Steenhagen, D. A., and R. L. Zimdahl. 1979. Allelopathy of leafy spurge (Euphorbia esula). Weed Science 27:1-3.

Symstad, A. J. 2004. Secondary invasion following the reduction of Coronilla varia (crownvetch) in sand prairie. American Midland Naturalist 152:183-189.

[USDA] US Department of Agriculture, Agricultural Research Service. 2005. TEAM Leafy Spurge. Available at: www.team.ars.usda.gov. Accessed 10 April 2009.

[USDA] US Department of Agriculture, Natural Resources Conservation Service. 2009. The PLANTS database. Available at: http://plants.usda.gov/. Accessed 10 April 2009.

Vanderhorst, J., S. Cooper, and B. Heidel. 1998. Botanical and vegetation survey of Carter County, Montana. Helena, MT, USA: Montana Natural Heritage Program. $116 \mathrm{p}$.

VILA, M., AND J. WeInER. 2004. Are invasive plant species better competitors than native plant species? Evidence from pair-wise experiments. Oikos 105:229-238.

Western Regional Climate Center. 2009. Western Regional Climate Center. Available at: http://www.wrcc.dri.edu/. Accessed 10 April 2009. 